Note

\section{Purification and Properties of Allothreonine Aldolase from Maise Seedlings}

\author{
Tutomu Masuda, Mitsuko Yoshino, \\ Izumi NISHIZAKI, Akira TAI* \\ and Hiroshi OzAKI* \\ Shitennoji Junior College, \\ Hanyuno, Habikino 583, Japan \\ *Institute for Protein Research, Osaka University, \\ Suita, Osaka 565, Japan
}

Received December 5, 1979

The allothreonine aldolase (L-allothreonine acetaldehyde-lyase EC 4.1.2.5) which catalyzes the reversible cleavage of allothreonine to glycine and acetaldehyde has been isolated from various animal tissues. ${ }^{1,2)}$ However the isolation of the enzyme from plant sources has not been reported. Recently we found a strong activity of allothreonine aldolase in the maise seedlings. The present paper reports a simple purification of allothreonine aldolase from maise seedling by the use of affinity chromatography together with the characterization of the enzyme.

Materials. Maise seeds (Zea mays L.) were purchased from Takii Seed Co. Kyoto. L-, D-Allothreonine were supplied by courtesy of Ajinomoto $\mathrm{Co}$. As a packing for an affinity chromatography, glycine-AH-Sepharose $4 \mathrm{~B}$ was prepared as follows;<smiles>O=C(CBr)ON1C(=O)CCC1=O</smiles>

\section{AH-Sepharose 4B}

(I)

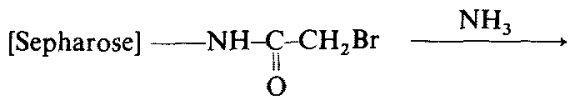

(II)<smiles>NCC(=O)N[Cl+2]O[AsH2]</smiles>

(III)

Bromoacetyl-ONSu (I) was prepared from bromoacetic acid and $N$-hydroxysuccinimide in the presence of DCC. To a solution of $1(1.25 \mathrm{mmol})$ in $62 \mathrm{ml}$ of $0.1 \mathrm{M}$ phosphate buffer ( $\mathrm{pH} 7.5$ ), $5 \mathrm{~g}$ of AH-Sepharose $4 \mathrm{~B}$ was added under stirring. The mixture was stirred for $30 \mathrm{~min}$ at $4^{\circ} \mathrm{C}$ Bromoacetyl-AH-Sepharose 4B (II) produced was separated from the solution by filtration and washed with three $500 \mathrm{ml}$ portions of $0.1 \mathrm{M}$ phosphate buffer $(\mathrm{pH} 7.5$ ) Amination of II was conducted with aqueous ammonia. A mixture of II and $60 \mathrm{ml}$ of $0.45 \mathrm{M}$ aqueous ammonia solution was allowed to stand for 5 days at room temperature. Under the condition, II was completely converted to glycine-AH-Sepharose 4B (III). III was filtered off and washed succesively with 1 liter of water and 2 liters of $0.01 \mathrm{M}$ phosphate buffer $(\mathrm{pH} 7.5)$. III was stored in $200 \mathrm{ml}$ of $0.01 \mathrm{M}$ phosphate buffer at $4 . \mathrm{C}$.

Enzyme assay. Aldolase activity was determined by the analysis of acetaldehyde by a modification of the method of Burbridge. ${ }^{3)}$ A mixture containing $20 \mu \mathrm{M}$ of $\mathrm{L}$ allothreonine, $10 \mu \mathrm{M}$ of pyridoxal 5-phosphate, an appropriate amount of enzyme solution, and $0.5 \mathrm{ml}$ of $0.1 \mathrm{M}$ phosphate buffer ( $\mathrm{pH} 7.5$ ) was incubated in a $20 \mathrm{ml}$ round bottom fiask with a glass stopper for $30 \mathrm{~min}$ at $37^{\circ} \mathrm{C}$ and was frozen at $-70^{\circ} \mathrm{C}$. This flask was connected to a glass tube containing $0.2 \mathrm{ml}$ of $2 \mathrm{~mm}$ aqueous solution of semicarbazide, previously cooled to $-70^{\circ} \mathrm{C}$, and then the system was evacuated and sealed. The flask was warmed to $30^{\circ} \mathrm{C}$ and kept at this temperature until two thirds of the content was transferred into the tube. Under the condition, acetaldehyde in the flask was completely transferred into the tube and converted to semicarbazone. After the content of the tube was brought to room temperature, it was made up to $6 \mathrm{ml}$ with $0.01 \mathrm{M}$ phosphate buffer $(\mathrm{pH} 7.5$ ). The concentration of semicarbazone was determined by measuring the absorbance at $222 \mathrm{~nm}$. A quantity of enzyme which produces $1.0 \mu \mathrm{mol}$ of acetaldehyde at $37^{\circ} \mathrm{C}$ was defined as one activity unit. Specific activity of the enzyme was expressed as units per mg protein.

Enzyme purification. The maise seedlings $(1 \mathrm{~kg})$ harvested at 5 days after germination were homogenized with 2 liters of $0.1 \mathrm{M}$ aqueous $\mathrm{K}_{2} \mathrm{HPO}_{4}$ in a Waring blendor. The homogenate was centrifuged $14,000 \mathrm{rpm}$ for $40 \mathrm{~min}$ and the supernatant was filtered through a gauze to remove floating particles. The filtrate was dialyzed against $0.01 \mathrm{M}$ phosphate buffer ( $\mathrm{pH} 7.5$ ) for $24 \mathrm{hr}$ to give $1,100 \mathrm{ml}$ of enzyme solution (enzyme solution of step 1). The ammonium sulfate-precipitated fraction ( 30 to $50 \%$ saturation) of the enzyme solution of step 1 was desalted with a Sephadex G-25 column $(4 \times 45 \mathrm{~cm})$. The eluate was concentrated to $10 \mathrm{ml}$ using a UK-10 filter (enzyme solution of step 2). The enzyme solution of step 2 was applied to a column of DEAE-cellulose $(2.3 \times 40 \mathrm{~cm})$, previously equilibrated with $0.01 \mathrm{M}$ phosphate buffer ( $\mathrm{pH} 7.5$ ), and the column was washed with 1 liter of the same buffer. The allothreonine aldolase adsorbed on the column was eluted with $400 \mathrm{ml}$ of $0.01 \mathrm{M}$ phosphate buffer $(\mathrm{pH} 7.5$ ) containing $0.05 \mathrm{M} \mathrm{KCl}$. The combined active fractions $(117 \mathrm{ml})$ was concentrated to $10 \mathrm{ml}$ using a UK-10 filter (enzyme solution of step 3). The enzyme solution of step 3 was divided into two 
Table I. Summary of Purification Procedures of Allothreonine Aldolase

\begin{tabular}{|c|c|c|c|c|}
\hline Enzyme solution & $\begin{array}{l}\text { Total protein } \\
(\mathrm{mg})\end{array}$ & $\begin{array}{l}\text { Total } \\
\text { units }\end{array}$ & $\begin{array}{l}\text { Specific activity } \\
\text { (unit/mg protein) }\end{array}$ & $\begin{array}{l}\text { Yield } \\
(\%)\end{array}$ \\
\hline Step 1 & 1716 & 220 & 0.13 & 100 \\
\hline Step 2 & 311 & 195 & 0.63 & 89 \\
\hline Step 3 & 14 & 113 & 8.0 & 51 \\
\hline$--\frac{--}{\text { Step } 4 \mathrm{~A}}$ & ----- & $-\frac{-}{78}$ & $-\frac{--}{84.0}-$ & $-\frac{-}{27}--$ \\
\hline Step 4B & --- & -- & $--\frac{--}{155.0}$ & 40 \\
\hline
\end{tabular}

equivalent portions. One portion was applied to the gel filtration and the other portion for the affinity chromatography. The gel filtration was carried out using a column of Sephadex G-100 $(4 \times 45 \mathrm{~cm})$. The elution was conducted with $0.01 \mathrm{M}$ phosphate buffer $(\mathrm{pH} 7.5)$. The active fractions were combined and concentrated to $10 \mathrm{ml}$ by using a UK10 filter (enzyme solution of step 4A). The affinity chromatography was carried out using a column of glycine-AH-Sepharose $4 \mathrm{~B}(1 \times 20 \mathrm{~cm})$. The enzyme adsorbed on a column was washed wih $40 \mathrm{ml}$ of $0.01 \mathrm{M}$ phosphate buffer ( $\mathrm{pH}$ 7.5). The active protein was specifically eluted with $120 \mathrm{ml}$ of the same buffer contain-

(a)

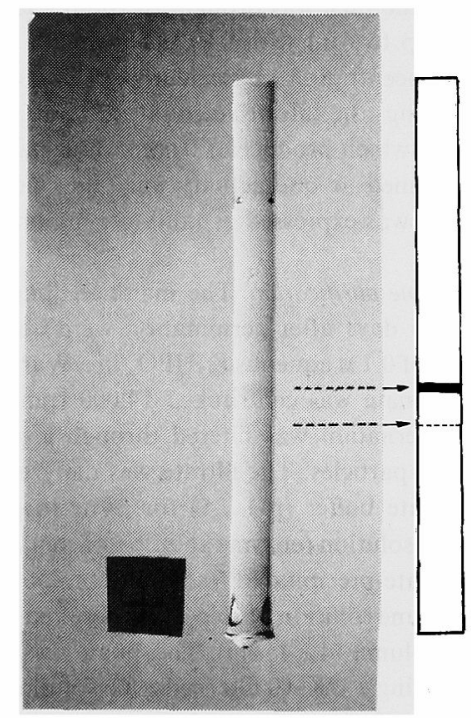

ing $0.05 \mathrm{M} \mathrm{KCl}$. The concentration of the eluate by the same method as above gave $10 \mathrm{ml}$ of enzyme solution (enzyme solution of step 4B). The purification of the enzyme at each step is summarized in Table $I$. The homogeneity of purified enzymes (step 4A and B) was determined by the gel electrophoresis according to the method of Weber and Osborn. " Figure 1b shows the sample of step $4 \mathrm{~B}$ to be homogeneous, whereas the sample of step 4A still contains a small amount of contaminant (Fig. 1a). Consequently the sample of step 4A showed a lower specific activity than the sample of step $4 B$. The use of glycine-AH-Sepharose $4 \mathrm{~B}$ instead of Sephadex G-100 is (b)

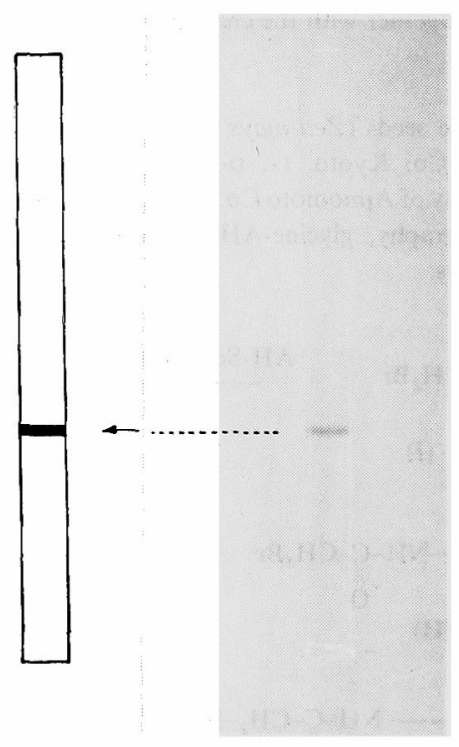

FIG. 1. Disc Electrophoresis of Purified Allothreonine Aldolase on SDS-Polyacrylamide Gels.

(a) The enzyme purified by the gelfiltration on Sephadex G-100 (sample A).

(b) The enzyme purified by the affinity chromatography on Glycine-AH-Sepharose 4B (sample B).

Column, $10 \%$ polyacrylamide gel containing $1 \%$ SDS $(0.5 \times 7 \mathrm{~cm})$; buffer, $0.25 \mathrm{M}$ tris $-\mathrm{HCl}(\mathrm{pH} 8.3)$ containing $0.2 \mathrm{\text {м }} \beta$-mercaptoethanol; sample protein, $20 \mu \mathrm{g}$ for each sample; electrophoresis, $4 \mathrm{~mA}$ per column for $3 \mathrm{hr}$ at room temperature; staining, $0.1 \%$ coomassie brilliant blue R-250 in $20 \%$ methanol-7\% acetic acid. 
advantageous not only in giving a pure enzyme in a good yield but also in the total bed volume of chromatography for the purification. The amount of glycine-AH-Sepharose 4B was only $1 / 20$ of Sephadex G-100.

Characterization of enzyme. The molecular weight of 120,000 was determined from gel filtration on Sephadex $G$ 100 as described by Andrews ${ }^{5 !}$ and the subunit molecular weight of 40,000 was determined by SDS polyacrylamide gel electrophoresis according to the method of Weber and Osborn. Although the present data are not enough to lead a conclusion, the single band found in the disc electrophoresis experiment is suggestive that the enzyme consists of three equivalent subunits as in the case of fructose diphosphate aldolase (fructose-1,6-diphosphate D-glyceraldehyde 3-phosphate-lyase, EC 4.1.2.13). ${ }^{\text {) }}$

The purified enzyme (step 4B) showed no aldolase activity in the absence of pyridoxal phosphate. The activity was, however, restored by the addition of pyridoxal phosphate to the enzyme. The $K m$ value for pyridoxal phosphate was found to be $35.1 \mathrm{~mm}$. When the enzyme was treated with dithiothreitol, the $K m$ value greatly decreased $(0.34 \mathrm{~mm})$. This observation is similar to that for enzymes from animal sources. "The optimum $\mathrm{pH}$ of the enzyme (pH $7.0 \sim 8.0$ ) was also found to be similar to that of enzyme from animal sources. ${ }^{81}$

The enzyme was highly specific to L-allothreonine. All other stereoisomers, i.e., D-allothreonine, $L$-threonine, and D-threonine, were totally inert to this enzyme. It was also confirmed that the enzyme catalyzed the formation of allothreonine from glycine and acetaldehyde by the following experiment. Glycine $(0.2 \mathrm{mmol})$ was incubated with enzyme $(5 \mu \mathrm{g})$ in the presence of acetaldehyde $(0.2 \mathrm{mmol})$ and pyridoxal phosphate $(0.2 \mathrm{mmol})$ in $0.5 \mathrm{ml}$ of phosphate buffer $(\mathrm{pH} 7.5)$ at $37^{\circ} \mathrm{C}$ for $30 \mathrm{~min}$. The paper chromatography of the product developed with $n$-BuOHMEK- $\mathrm{H}_{2} \mathrm{O}-15 \%$ aq. $\mathrm{NH}_{3}(5: 3: 1: 1)$ showed only two ninhydrin positive spots corresponding to glycine and allothreonine but no detectable spot corresponding to threonine.

There are discordant observations about the specificity of allothreonine aldolase. Some literatures suggest that the enzyme is able to decompose both threonine and allothreonine. $^{2,93}$ The present result strongly suggests that allothreonine aldolase is only active to decompose L-allothreonine.

The purified enzyme was also found to function as a serine transhydroxymethylase (EC 2.1.2.1) in the presence of tetrabydrofolic acid. The formation of serine from glycine and formaldehyde and the degradation of serine to glycine were confirmed by the following experiments. Serine $(0.2 \mathrm{~mol})$ was incubated with the enzyme $(5 \mu \mathrm{g})$ in the presence of pyridoxal phosphate $(0.2 \mathrm{mmol})$ and tetrahydrofolic acid $(0.2 \mathrm{mmol})$ in $0.5 \mathrm{ml}$ phosphate buffer (pH 7.5) at $37^{\circ} \mathrm{C}$ for $30 \mathrm{~min}$. The paper chromatography of the reaction product developed with the same solvent as mentioned above showed a significant ninhydrin positive spot corresponding to glycine. A mixture of glycine $(0.2 \mathrm{mmol})$ and formaldehyde $(0.2 \mathrm{mmol})$ was also incubated with $5 \mu \mathrm{g}$ of enzyme under the same conditions as mentioned above. The formation significant amount of serine was confirmed by the paper chromatography.

The results are indicative that allothreonine aldolase is not separable with serine transhydroxymethylase as is known in the case of enzymes from animal sourse. ${ }^{10}$ When this fact is taken into account, the present work may provide a useful purification method (affinity chromatography) and a convenient assay (allothreonine aldolase activity monitoring the purification step) for the purification of serine transhydroxymethylase of various enzyme sources.

\section{REFERENCES}

1) G. Riario-Sforza, R. Pagani and E. Marinells, Eur. J. Biochem., 8, 88 (1969).

2) M. Akhtar and H. A. El-Obeid, Biochim. Biophys. Acta, 258, 791 (1972).

3) T. N. Burbridge, C. H. Hine and A. F. Schick, J. Lab. and Clin. Med, 35, 983 (1950).

4) K. Weber and M. Osborn, J. Biol. Chem., 250, 7894 (1975).

5) P. Andrews, Methods Biochem. Anal., 18, 1 (1970).

6) E. Stellwagen, J. Mol. Biol., 106, 903 (1976).

7) L. Schirch, M. Edmiston, M. S. Chen, D. Barra, F. Bossa, L. Hinds and P. Fasella, J. Biol. Chem., 248, 6456 (1973).

8) M. A. Karasek and D. M. Greenberg, J. Biol. Chem., 227. 191 (1957).

9) L. I. Malkin and D. M. Greenberg, Biochim. Biophys. Acta, 85, 117 (1964); M. Akhtar, H. A. El-Obeid and P. M. Jordan, Biochem. J., 145, 159 (1975).

10) L. Schirch and T. Gross, J. Biol. Chem., 243, 5651 (1968). 